\title{
Geology of Northern
}

Kanaga Island

Alaska

By ROBERT R. COATS

INVESTIGATIONS OF ALASKAN VOLCANOES

GE OLOGICAL S U R VEY B U L LET I N $1028-\mathrm{D}$

Prepared in cooperation with the Office, Chief of Engineers; $U$. S. Army

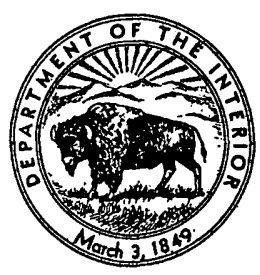




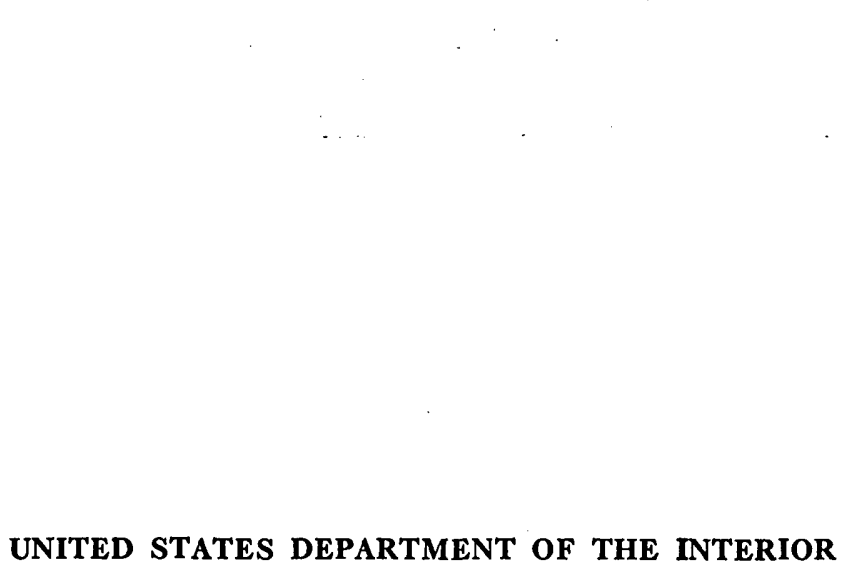

Fred A. Seaton, Secretary

GEOLOGICAL SURVEY

Thomas B. Nolan, Director 


\section{PREFACE}

In October 1945 the War Department (now Department of the Army) requested the Geological Survey to undertake a program of volcano investigations in the Aleutian Islands-Alaska Peninsula area. The first field studies, under general direction of G. D. Robinson, were begun as soon as weather permitted in the spring of 1946. The results of the first year's field, laboratory, and library work were assembled as two administrative reports. Part of the data was published in 1950 in Geological Survey Bulletin 974-B, Volcanic activity in the Aleutian arc, by Robert R. Coats. The remainder of the data has been revised for publication in Bulletin 1028.

The geologic and geophysical investigations covered by this report were reconnaissance. The factual information presented is believed to be accurate, but many of the tentative interpretations and conclusions will be modified as the investigations continue and knowledge grows.

The investigations of 1946 were supported almost entirely by the Military Intelligence Division of the Office, Chief of Engineers, U. S. Army. The Geological Survey is indebted to the Office, Chief of Engineers, for its early recognition of the value of geologic studies in the Aleutian region, which made this report possible, and for its continuing support. 
, 


\section{CONTENTS}

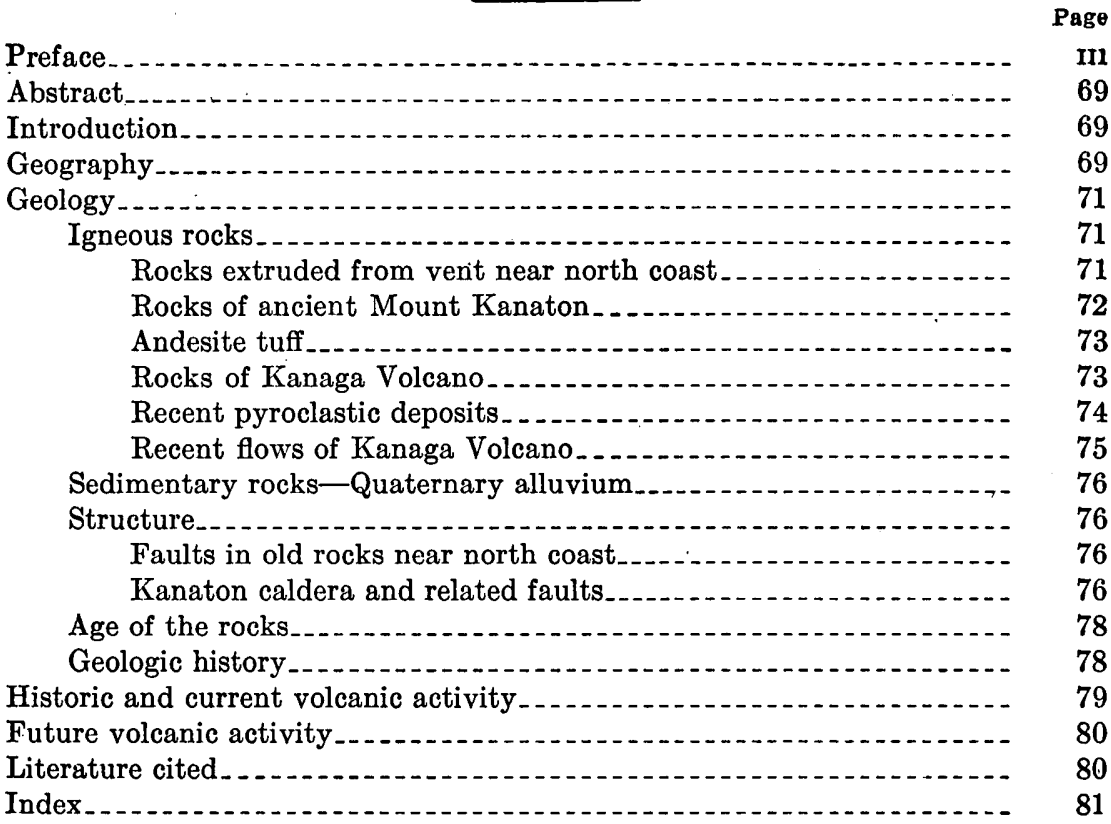

\section{ILLUSTRATIONS}

Page

Plate 15. Geologic map of northern Kanaga Island, Alaska........ In pocket

16. Aerial view of Kanaga Volcano from the east. . .

Figure 5. Map of the Alaska Peninsula and Aleutian Islands...... 70 



\title{
INVESTIGATIONS OF ALASKAN VOLCANOES
}

\section{GEOLOGY OF NORTHERN KANAGA ISLAND, ALASKA}

\author{
By Robert R. Coats
}

\section{ABSTRACT}

The northern part of Kanaga Island, one of the central Aleutian Islands, was examined briefly in July 1946. The oldest rocks recognized comprise a sequence of basalt flows and tuff beds, remnants of a cone that was formed near the present north coast. These rocks are believed to be late Tertiary in age. After the cone was partly destroyed by erosion, a basaltic shield volcano called Mount Kanaton was built nearby, and on its flanks at least two composite basalt cones were formed. Near the end of Pleistocene time, following an eruption of andesitic ash, the central part of the shield volcano and the cones on its flanks collapsed and disappeared as a result of downfaulting, leaving a great caldera. Renewed eruptions from the floor of the caldera built up the present cone of Kanaga Volcano, which has been intermittently active during historic time. All of the caldera rim except the southeastern part has been removed either by downfaulting or marine erosion. Some recent explosive eruptions have blanketed the island with basaltic and andesitic pumice, and have apparently flung blocks of lava a distance of as much as 30 miles. Basaltic lava was erupted from the sides of Kanaga Volcano as recently as 1904 and 1906. Present activity is mild and fumarolic, but minor, infrequent explosive eruptions and quieter extrusions of lava can be expected.

\section{INTRODUCTION}

The purpose of this report is to describe briefly the geology, history of volcanic activity, and nature of future volcanic activity of the extreme northern part of Kanaga Island.

Field work was carried out between July 12 and July 22, 1946, by Robert R. Coats, geologist, assisted by Will F. Thompson, Jr., recorder. Performance of the work would have been impossible without the cooperation of officers and men of the U. S. Army, especially of Lt. Col. R. E. Ware, post engineer, Adak, and Lt. Col. C. E. Johnson, port commander, Adak.

\section{GEOGRAPHY}

Kanaga Island is one of the Andreanof group of the Aleutian Islands. It lies between the parallels of $51^{\circ} 40^{\prime} \mathrm{N}$. and $51^{\circ} 57^{\prime} \mathrm{N}$., and between the meridians of $177^{\circ} 03^{\prime} \mathrm{W}$. and $177^{\circ} 42^{\prime} \mathrm{W}$., and is one 


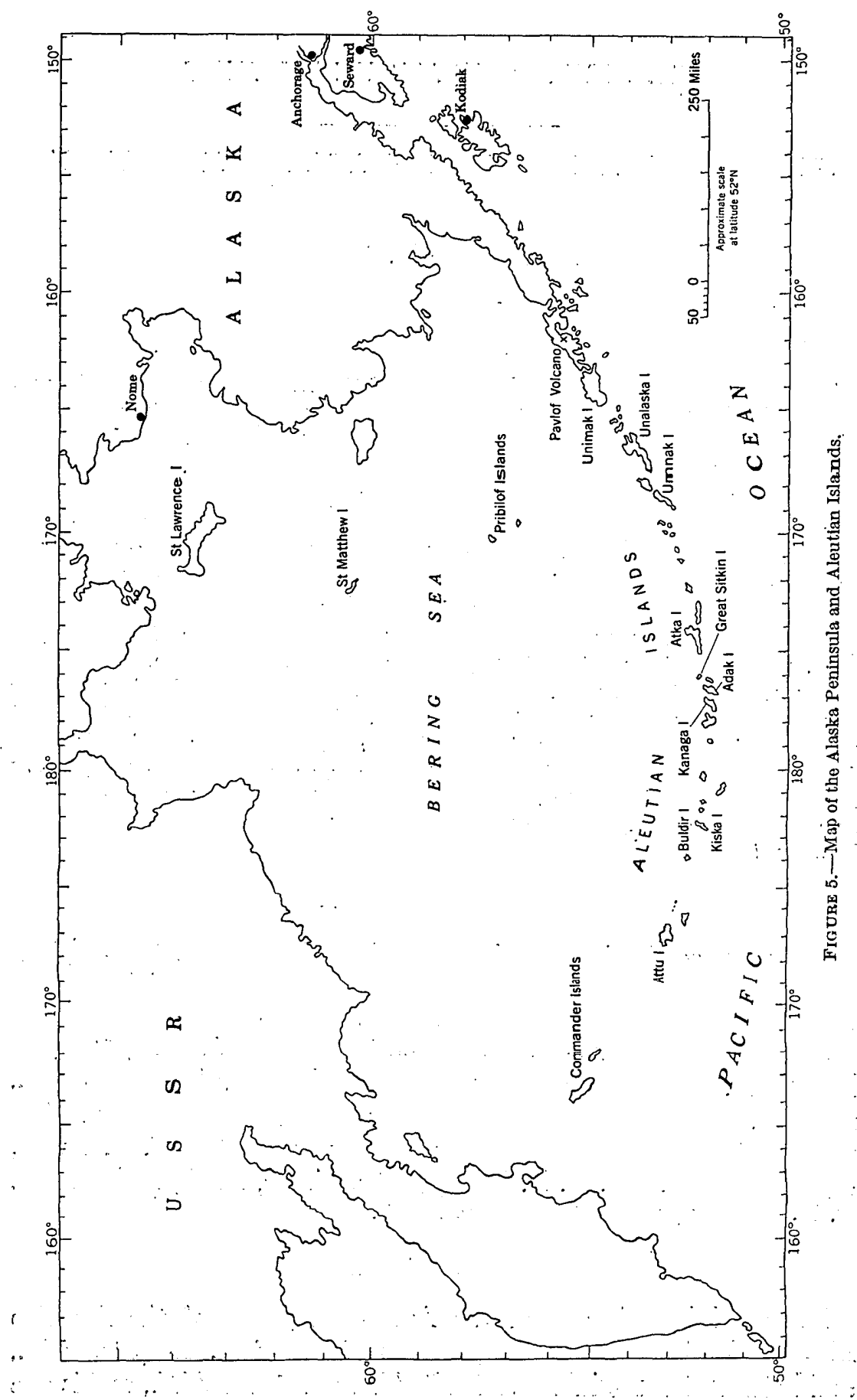




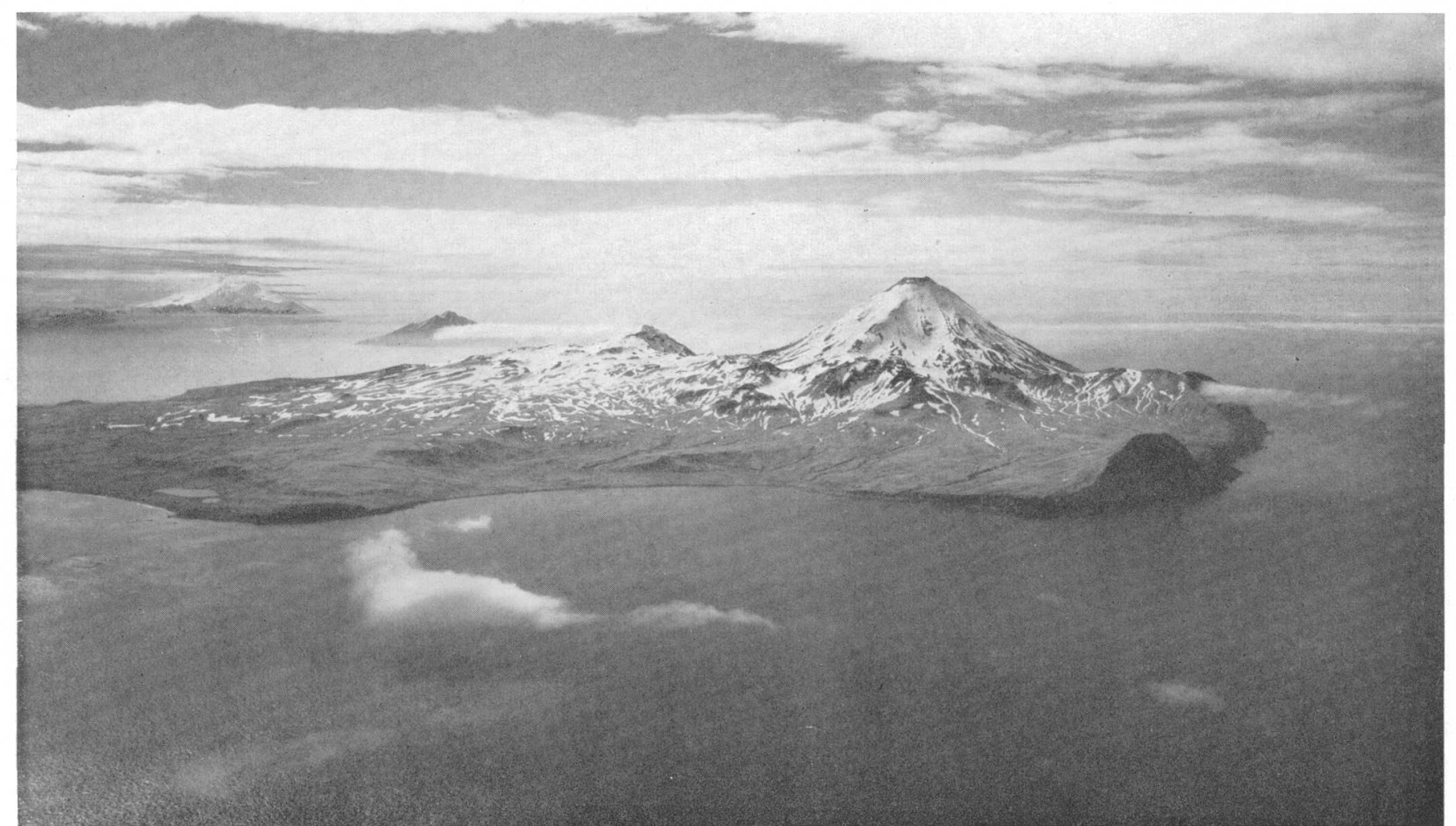

The rim of an ancient caldera is at the left of the symmetrical cone. The high cliff nearest the camera is that of Round Head. Bobrof Island and the mountains of northern Tanaga Island are visible in the distance to the left. Photograph by U. S. Navy. 
of the most southerly of the Aleutian. Islands (fig. 5). The area herein called northern Kanaga Island is made up of the part of the island north of latitude $51^{\circ} 52^{\prime} \mathrm{N}$.

The outline of Kanaga Island on the map may be likened to that of a pistol, the barrel pointing west, and the butt extending north. The landscape of the southwestern part of the island-the part coinciding with the barrel and breech of the pistol-consists of successive marine terraces, the highest of which is 600 feet in altitude. The terraces are dotted with lakes and partly dissected by streams. On northern Kanaga Island an arcuate ridge, which trends northeastward and is convex to the southeast, rises to an altitude of 2,600 feet (pl. 16). Many small ridges extend to the south and east from the arcuate ridge, and a few variously trending minor "splinter" ridges (Gilbert 1928, p. 80-81) project from its steep inner scarp. This scarp faces, across a large depression, the simple cone of Kanaga Volcano, 4,305 feet in altitude, the most conspicuous feature of the island. In the extreme southeastern part of the depression lies an unnamed lake, nearly 1 mile long, which has no surface outlet. The cliffs of Round Head, the eastern extremity of the island, expose a section through the southwestern flank of a minor cone, the site of whose vent is now beneath the Bering Sea.

\section{GEOLOGY}

The geologic history of northern Kanaga Island is essentially the history of the development of an ancient shield volcano (herein called Mount Kanaton after an obsolete name for the island), its decapitation by eruption and collapse, and the building of Kanaga Volcano within its broken rim. The rocks belonging to the several stages are discussed in chronologic order of formation, and they are shown on the geologic map (pl. 15). The petrography of the rocks has been discussed in more detail in a previous report (Coats, 1952).

\section{IGNEOUS ROCKS}

\section{ROCKS EXTRUDED FROM VENT NEAR NORTH COAST}

The rocks of a deeply dissected small basaltic cone, cropping out on the north shore, are apparently the oldest rocks exposed on northern Kanaga Island. They are made up largely of lava flows, but include a few tuff beds. The lava flows are composed mostly of finegrained, dense, dull greenish gray basalt. The basalt contains abundant labradorite phenocrysts, less conspicuous augite phenocrysts, and accessory hypersthene, olivine, hornblende, and magnetite grains in a groundmass of plagioclase laths, magnetite dust, and orthoclase(?). These are the only rocks on northern Kanaga Island 
showing evidence of widespread hydrothermal alteration. The dips of the flows indicate that their vent was about 2 miles east of the present summit of Kanaga Volcano. The remnants of the cone are overlapped by the younger basalt flows of ancient Mount Kanaton.

\section{ROCKS OF ANCIENT MOUN'T RANATON}

A thick sequence of basalt and andesite lava flows is exposed on the inner face of the arcuate ridge of Mount Kanaton and on the radial ridges diverging from it. The flows, averaging about 20 feet in thickness, have an aggregate thickness of more than 1,500 feet. Low outward dips of $5^{\circ}-14^{\circ}$ indicate that the flows issued from a vent near the present vent of Kanaga Volcano. The distribution and dips of the lava flows indicate that they once formed a broad domelike shield volcano, much more extensive but lower than the present cone.

Weathered surfaces of the rocks are dark gray, but fresh surfaces are medium-to-light gray. The rocks consist of phenocrysts of labradorite, olivine, hypersthene, and augite, and accessory magnetite, in a groundmass of plagioclase laths, augite rods, magnetite granules, and interstitial glass or orthoclase(?). A few of the lava flows contain hornblende and apatite.

In general the proportion of hypersthene to olivine increases from the bottom to the top of the sequence of flows. Olivine basalt is common in the lowermost flows, olivine-hypersthene basalt in the intermediate flows, and hypersthene basalt and andesite in the highest ones.

Thin basalt flows interbedded with tuff-breccia-the remnants of a composite cone built on the flanks of Mount Kanaton-crop out near the west coast. The beds dip nearly $30^{\circ}$ away from the center, which was about half a mile south of the present summit of Kanaga Volcano. The rocks of these flows differ little from those of the earlier flows of Mount Kanaton, except that they contain a higher proportion of phenocrysts. Most of the flows consist of hypersthene basalt and olivine-hypersthene basalt, but a few consist of hornblende andesite. The fragments in the tuff-breccia are similar to the basalt flows in composition.

Many thick, low-dipping, olivine basalt flows, exposed in the vicinity of Round Head, appear to have issued from a vent on the northeastern slopes of Mount Kanaton. The flows are typically light pinkish gray or pale gray, and contain conspicuous large phenocrysts of dark-green augite and smaller phenocrysts of olivine and plagioclase in a medium-grained groundmass. On the north, the lava flows apparently banked against a sea cliff cut in early flows from Mount Kanaton. On the south, the latest flow from this northeastern vent 
overlaps a flow from Mount Kanaton. The outer slopes of the cone built of these flows are somewhat less dissected than are those of the cone near the west coast, indicating that the cone near Round Head may be somewhat younger.

\section{ANDESITE TUEF}

Andesite tuff forms a thin blanket, widespread over northern Kanaga Island south and east of the cone of Kanaga Volcano and the curving ridge bordering it, except on the summits of the high ridges and on the steepest slopes. The tuff blanket commonly is only a few feet thick, but locally is as much as 30 feet thick. The tuff is well exposed in a small gully about 3,000 feet south of the southeast corner of the large lake and in a stream-cut bank about a mile southeast of the same corner of the lake. The tuff is a rather uniform, fine-grained rock, only slightly stratified. Where unaltered, it is light gray; where weathered, it is pale buff. Near the stream-cut bank, the tuff is yellowish gray and contains fragments of pumice as much as a quarter of an inch in diameter. The pumice fragments are rather fragile; after shipment only 5 percent of a sample of the coarser material was retained on a 10-mesh sieve. Of the part thus retained, about half was made up of fragments of accidental and accessory rocks, the rest of essential and cognate material, largely pumice and cognate crystalline rocks.

The accidental material includes quartz-oligoclase-biotite hornfels, amphibolite, anthophyllite-feldspar schist, and biotite schist. It is inferred that the walls of the magma chamber from which this tuff was erupted extended down to the sialic crustal rocks of continental type, not now exposed anywhere on Kanaga or adjacent islands, so far as is known.

The principal essential and accessory constituents are labradorite, green hornblende, brown basaltic hornblende, augite, hypersthene, magnetite, apatite, and glass. All these constituents except the green hornblende are present in older volcanic rocks of the island and could have been derived from them; the older volcanic rocks probably were fragmented by volcanic explosions. Green hornblende, however, is very rare in extrusive rocks (the color of the hornblende typical of most extrusive rocks is reddish brown). Its presence suggests that the tuff was for the most part the product of $a^{*}$ body of deep-seated magma that was erupted so rapidly the hornblende did not completely oxidize.

\section{ROCKS OF KANAGA VOLCANO}

The cone of Kanaga Volcano consists of interbedded hypersthene basalt and hypersthene andesite flows, scoria layers, and beds of 
tuff-breccia. Most of the rock exposures on the mountain are of lava flows, but a few cliff exposures indicate that the interior of the cone probably contains a high proportion of fragmental material. Around the base of the steeper part of the cone are wide block-strewn areas that have the characteristics of mudflows.

The rocks are dark gray to black, generally vesicular, and are characterized by labradorite phenocrysts, 2-4 millimeters long, and smaller augite and hypersthene phenocrysts set in a groundmass of plagioclase microlites, augite needles, and brown glass.

\section{RECENT PYROCLASTIC DEPOSITS}

Beyond the immediate slopes of the present cone, turf and underlying peat rest on a mantle of volcanic ash and pumice, which has a maximum measured thickness of about 7 feet. Most of the ash and pumice was presumably erupted from Kanaga Volcano while the present cone was being built, and some may have been derived from explosive eruptions on other islands. This mantle has not been shown on the geologic map; because it is so widely distributed it would obscure the details of the bedrock geology. The ash is generally firm and impermeable, but it contains a few beds of pale pumice that are permeable and that serve as aquifers. The removal of these permeable layers by headward erosion of small streams has resulted in the development of miniature caves in the ash.

The large lake between the cone and the arcuate ridge southeast of it has often been showered with ash and pumice. Much of the coarser pumice was light enough to float, and has been concentrated on the east and west shores of the small island in the lake, and in a large bar of water-sorted stratified pumice rising about 30 feet above water level in the extreme southeast corner of the lake. This material was not separately mapped but was included with the alluvium.

Following the deposition of the pumice, two more eruptions of pyroclastic material from Kanaga Volcano occurred. These are of special interest because they provide clues to the kind of explosive activity that can be expected from the volcano. Their products, however, are insignificant in volume.

During the first of these eruptions, pumice was sprinkled over the slopes of the volcano in two layers, the earlier one consisting of pale-gray andesitic pumice, and the later one, of dark pumice derived from a basaltic magma that appears to have remelted and partly digested the andesitic rock.

During the second eruption, blocks of previously consolidated pale-gray compact basalt were flung over the landscape, producing numerous imposing impact craters where they fell on the lower slopes of the volcano and producing other imposing but widely separated 
craters at least as far as $2 \frac{1}{2}$ miles from the summit. The largest impact crater observed has major and minor diameters of 20 and 15 feet; and is 5 feet deep. Some craters that are 5 feet or less in diameter are as much as 3-4 feet deep. The basalt blocks contain labradorite and augite phenocrysts and accessory magnetite in a groundmass of equant feldspar grains and pale glass. Fragments apparently of the same rock, weighing only a few pounds, are present on the slopes of Mount Moffett on Adak Island and near Hot Springs Bay on Tanaga Island (Coats, 1956).

\section{RECENT FLOWS OF KANAGA VOLCANO}

The youngest rocks associated with Kanaga Volcano comprise four basalt flows emitted from the cone during historic or late prehistoric time. The oldest of these flows, referred to as the early southwestern flow, appears to have issued from a fissure on the southwest side of the cone at an altitude of about 3,900 feet. It is now covered by a younger flow, called the late southwestern flow, at an altitude of about 500 feet.

The next younger flow-the southern flow-apparently issued from the same vent as that from which the early southwestern flow issued. It was ponded against the base of the arcuate ridge to a depth of at least 100 feet. This flow is perhaps the one emitted in 1904 (p. 79).

A flow that also issued from a fissure high on the southwestern flank of the cone-the late southwestern flow-covers the lower end of the early southwestern flow and extends past the caldera wall to the sea. Another flow-the northeastern flow-moved northeastward from the crater. Its terminus is marked by a flow scarp about 100 feet high on a grassy flat about 600 feet above sea level.

The late'southwestern flow and the northeastern flow were probably erupted in 1906 (p. 79). All but the oldest of the four flows were extruded after the two explosive eruptions described in the section "Recent pyroclastic deposits."

The flows resemble one another closely. Their thickness on the steep slopes of the cone does not exceed 20 feet. (On the geologic sections of plate 15 their thickness has been exaggerated for clarity.) The southern and northeastern flows contain labradorite phenocrysts, ranging in length from 0.1-3 millimeters, smaller augite, hypersthene; and magnetite phenocrysts, and a few large olivine phenocrysts, as much as 6 millimeters across, in a groundmass of plagioclase laths; augite rods, magnetite granules, and brownish glass. . The two southwestern flows are similar in composition to the southern and northeastern flows, except that they do not contain olivine.' 


\section{SEDIMENTARY ROCKS-QUATERNARY ALLUVIUM}

A large area of alluvium occurs on the east shore of the island south of Round Head. Its surface forms a plain half a mile wide, rising from a few feet above sea level at the outer edge to about 40 feet above sea level at the inner edge. Where exposed by marine erosion the alluvium consists of intermingled ash, wind-blown sand, and peat. The plain probably is underlain in part by stream-transported ash and pumice from the outer slopes of former Mount Kanaton.

Narrow beaches covered by rounded boulders several feet across fringe the island. The highest parts of the beaches are as much as 20 feet above normal high water.

\section{STRUCTURE}

The structure of northern Kanaga Island is diagramatically illustrated by the geologic section of plate 15 . As nearly as can be determined, the rock units shown on plate 15 have retained their initial dips, but have been displaced relative to one another by numerous faults. Some of the faults are probably older than the formation of the caldera, and some came into existence at the time of formation of the caldera. Northern Kanaga Island appears to have been a relatively stable platform for a long time. After the volcanic structures were built, the platform as a whole was subjected to vertical movements, and parts were subjected to downfaulting, which caused fragmentation. Deformation by compressive stress has not occurred.

\section{FAULTS IN OLD ROCKS NEAR NORTH COAST}

A group of faults cuts the rocks older than those of Mount Kanaton near the north coast. The trends of these faults range from N. $47^{\circ} \mathrm{W}$. to $\mathrm{N} .30^{\circ} \mathrm{W}$. All the faults are vertical, or very nearly so. Data are not available for determining the direction of movement. The wall rocks of some of the faults have been hydrothermally altered for considerable distances from the faults, but the nature of the alteration has not been determined.

\section{KANATON CATDERA AND RELATED FAULTS}

The arcuate ridge, its steep inner face, and its radially disposed outer ridges constitute the most unusual feature on Kanaga Island. The outward dips of the flows composing the ridge indicate a common source from a center near the present summit of Kanaga Volcano, and it is partly on this basis that Mount Kanaton is assumed to have existed. The ridge is clearly a remnant of a former large volcanic mountain. Several explanations for the disappearance of most of the 
upper parts of Mount Kanaton and the formation of the ridge are considered.

The ridge could conceivably be a cliff produced by marine erosion, except that sea cliffs developed in relatively simple structures commonly are straight or convex, rather than concave. It might be explained as the result of a gigantic explosion that destroyed the entire summit area. Such an explosion, however, would be expected to leave enormous quantities of coarse, angular basaltic rock debris-volcanic breccia-on the flanks of the volcano. No breccia deposits are present; instead, the pyroclastic eruption preceding the formation of the ridge deposited very fine andesitic tuff in a thick bed on the outer slopes of Mount Kanaton.

The most tenable explanation for the destruction of the summit area of ancient Mount Kanaton seems to be that of collapse by downfaulting of the central part, forming a caldera of which the arcuate ridge is a remnant. How the space for the collapsed superstructure of the volcano was formed remains an unsolved problem. The total volume of the blanket of ejected andesitic tuff, even assuming an average thickness of about 30 feet, which is the maximum measured thickness, is inadequate to account for the space into which the upper part of the cone collapsed. Additional space to accommodate the collapsed. roof was presumably provided by withdrawal of lava through submarine extrusion or intrusion at depth.

There is considerable evidence to support the conclusion that the arcuate ridge was formed by downfaulting of the central part of Mount Kanaton along lines tangential to the contours of the mountain. The simple outlines and undissected form of the inner face suggest that it is a fault scarp. On the south side of the ridge, south of the highest point, a recent fault parallels the crest of the ridge; the north side of the fault is downthrown a few feet, as shown by the displacement of the surface where the fault crosses ridges. This fault is considered to be a branch of one of the faults along which subsidence took place. The major caldera-forming faults are not exposed. In a few places the scarp may nearly coincide with the position of a principal caldera-forming fault. A zone of rock alteration in the wall of the caldera, just north of the northeast corner of the lake, suggests the presence of one of the major caldera-forming faults. The conspicuous short ridge at the west end of the lake and the northward-trending ridge east of the lake are both believed to be down-dropped blocks that have remained at a relatively high elevation. The arcuate ridge may be the remnant of a rim that originally encircled the caldera, but which was destroyed by subsequent marine erosion or downfaulting, or the caldera may never have been a completely enclosed depression. 


\section{AGE OF THE ROCKS}

The relative age of the rocks of northern Kanaga can be deters mined fairly accurately from superposition and the relative degree of dissection by erosion, but the actual geologic age of the rocks can be determined only with difficulty, as none are fossiliferous.

The shield volcano of Mount Kanaton does not appear to have been glaciated at the level of the present caldera rim; although a volcano on Tanaga Island, a few miles to the west, shows much evidence of vigorous glaciation at corresponding altitudes and some evidence of glaciation down to sea level. Moreover, the caldera wall itself is unglaciated, although ridges of similar altitude on southern Adak Island have been trimmed and sharpened by glacial erosion. On the other hand, Mount Adagdak, an isolated mountain on nearby Adak Island, is only 500 feet lower than the arcuate ridge, but has. not been glacially dissected though it is of preglacial age. It is inferred that glaciers will form on a mountain whose altitude is about the same as that of the lower limit for the accumulation of glacial ice if the mountain is one of a group of peaks of about the same height, but not if it is an isolated peak. The lack of evidence for development of glacial cirques on the caldera rim does not, therefore; indicate that the caldera was formed after the close of the glacial epoch in this area.

The absence of signs of glaciation seems best explained by assuming that the construction of Mount Kanaton and the composite volcano on its southwest flank was relatively rapid, beginning in late Tertiary time and continuing into Quaternary time. Therefore, glaciers had little opportunity to develop on Mount Kanaton; those that may have existed were probably small and confined to the slopes of the volcano above the level of the present caldera rim.

On the basis of the foregoing interpretation of the age of Mount Kanaton, the lava flows extruded from the vent on the north coast are assumed to be late Tertiary in age, the flows of the composite cone built on the flanks of Mount Kanaton are believed to be late Tertiary and Quaternary in age, and the present cone of Kanaga Volcano is believed to be Quaternary in age, as are the pyroclastic and alluvial deposits lying on bedrock. The collapse that created the caldera probably occurred toward the close of the Pleistocene epoch.

\section{GEOLOGIC HISTORY}

The known geologic history of northern Kanaga Island began with the opening of a vent about 2 miles east of the present summit of Kanaga Volcano and the construction of a small cone. The cone; which was made up largely of basalt flows, was partly destroyed by marine and subaerial erosion. A broad shield volcano-ancient 
Mount Kanaton-was then built of basalt and andesite flows that were extruded from a vent near the present vent of Kanaga Volcano. After a brief erosional interval, vents on the flanks of Mount Kanaton were opened. A cone made up of basaltic flows and scoria was built on the southwestern, flank, and a similar cone, consisting largely of thick lava flows, was built seaward from Round Head, which is on the present northeastern. shore. After a period of quiescence and erosion, Mount Kanaton erupted violently, covering all but the steepest slopes of northern Kanaga Island with a thick blanket of andesitic tuff. During or soon after this eruption the upper part of the cone collapsed, forming a caldera. The northern and western threequarters of the caldera rim subsequently disappeared beneath the sea, either by downfaulting or as a result of marine erosion. After a brief interval during which the blanket of andesitic tuff was partly eroded, the eruptions that produced the present cone of Kanaga Volcano began and continued.sporadically to the present time.

\section{HISTORIC AND CURRENT VOLCANIC ACTIVITY}

The earliest volcanic activity on Kanaga Island was described as "smoke" rising above Kanaga Volcano in 1790 and 1791 (Becker, 1898). Information given by Grewingk (1850) suggests that the "smoke" was merely steam from hot springs around the base of the cone. Grewingk gives Luetke as a reference for the reported emission of smoke in 1827. The volcano was described as having been very active in 1904 (Jaggar, 1927). An eruption in May 1906 was reported in a letter to the writer from Simeon Oliver, teacher at Atka, who obtained his information from William Dirks of Atka. According to Dirks, who was trapping near Kanaga Volcano at the time, earthquakes occurred and lava poured down the east and west sides of the cone to the sea. It is possible that these lava flows are the ones now.present on the southwest and northeast sides of the cone; however, only one of them reached the sea.

The existence of fumaroles on Kanaga Island was reported at a very early date. According to Grewingk (1850, p. 208) the occurrence of fumaroles and the collection of sulfur were reported by Tolstykh, the discoverer of the Andreanof group.. The sulfur was probably collected by natives for use as tinder (Collins, Clark, and Walker, 1945, p. 26).

Hot springs at the foot of the mountain, mentioned in many of the early records, were not found in 1946. At present, the most conspicuous fumaroles are those near the summit of the mountain on the southeast, south, and southwest :sides. The most spectacular of them emits so much vapor that the resulting cloud can be seen on a clear day from Adak. This fumarole was not visible in the fog pre- 
vailing when we climbed Kanaga volcano, but several others, both within the crater and a short distance outside, were examined: Within the crater, which has a maximum depth of about 200 feet, several fumaroles were found in an area about 200 feet square, mostly floored with white or brightly colored mud, presumably opaline products of rock disintegration. Crusts of sulfur are common in fissures through which the hot gases ascend. The maximum temperature measured was $104^{\circ} \mathrm{C}$, and a faint odor of hydrogen sulfide was detected. On the southeast side of the volcano, several fumaroles emitted odorless water vapor in small quantities. Some of these fumaroles are as much as 200 feet below the crater rim. The maximum temperature measured was $102^{\circ} \mathrm{C}$.

\section{FUTURE VOLCANIC ACTIVITY}

On the basis of the historic and geologic records, Kanaga Volcano must be regarded as an active volcano. Analogy of Kanaton caldera with calderas of other volcanic centers indicates that major eruptions such as the one that produced Kanaton caldera are not likely to occur in the near future, but minor infrequent eruptions of ash and coarser fragments, sometimes accompanied by the emission of lava, are to be expected. Nearby islands such as Adak and Tanaga may receive falls of ash during these eruptions, but, judging from the thicknesses of ash beds that were probably derived in part from similar eruptions; the ash deposited on the neighboring islands from any one eruption on Kanaga Island should not exceed a few inches in thickness.

\section{LITERATURE CITED}

Becker, G. F., 1898, Reconnaissance of the gold fields of southern Alaska, with some notes on the general geology: U. S. Geol. Survey 18th Ann. Rept., pt. 3, p. 16-17.

Coats, R. R., 1952, Magmatic differentiation in Tertiary and Quaternary volcanic rocks from Adak and Kanaga Islands, Aleutian Islands, Alaska: Geol. Soc: America Bull., v. 63, p. 485-514.

1956, Reconnaissance geology of some western Aleutian islands: U. S'. Geol. Survey Bull. 1028-E. [In press.]

Collins, H. B., Jr., Clark, A. H., and Welker, E. H., 1945, The Aleutian Islands: Their people and natural history: Smithsonian Inst., Washington, War Background Studies, no. 21.

Gilbert, G. K., 1928, Studies of Basin Range structure: U. S. Geol. Survey Prof. Paper 153, p. 80-81.

Grewingk, Constantin,. 1850, Beitrag zur Kenntniss der orographischen und geognostischen Beschaffenheit der Nordwest Küste Amerikas, mit den anliegenden Inseln: Russ. K. min. Gesell. Verh., St. Petersburg, 18481849 , p. 208.

Jaggar, T. A., 1927, Volcano Letter, no. 116, Hawaiian Volcano Observatory. Honolulu, T. H. 


\section{INDEX}

\begin{tabular}{|c|c|}
\hline Page & Page \\
\hline Alluvium. & Kanaga Volcano, age of cone........ \\
\hline ndesite tuff. & descriptlon. . . . . \\
\hline 74 & history \\
\hline asalt, hydrothermally altered. & \\
\hline eaches.............. & $\begin{array}{l}\text { dava flows, Kanaga Volcano........ } \\
\text { Mt. Kanaton... }\end{array}$ \\
\hline aldera, formation of. & \\
\hline$\cdots$ & [t. Ada \\
\hline $73-74$ & Mt. Kanaton, destruction................. $76-77,78$ \\
\hline flow & history \\
\hline 71-72 & lava flows. ...... \\
\hline tuff. & $\begin{array}{l}\text { Mt. Moffett. } \\
\text { Mudflows.... }\end{array}$ \\
\hline D & Pumice... \\
\hline 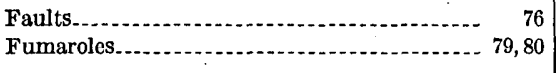 & Pyroclastic deposits. \\
\hline & ound Head........ \\
\hline 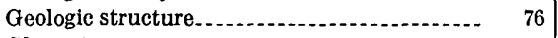 & \\
\hline Glacia & \\
\hline & 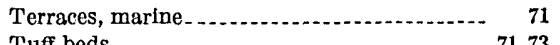 \\
\hline ( & beds. \\
\hline Bay & \\
\hline Hydrothermal alteration of rock & $y$, futu \\
\hline et $c$ & - \\
\hline
\end{tabular}

